\title{
PRESERVE FOR FUTURE REFERENCE.
}

Commonwealth of cattussacthusetts.

\section{THE GYPSY AND BROWN-TAIL}

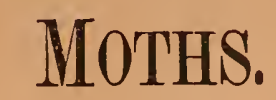

\section{BULLETIN No. 1.}

Issued from the Office of the SUPerintexdeat for Suppressing the Gypsy and Brown-tail Mothis.

BOSTON :

WRIGHT \& POTTER PRINTING CO., STATE PRINTERS, 18 Post Office Sqcare.

\section{QL \\ 548 \\ M 312}

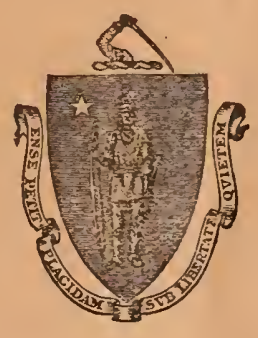

$$
1905 .
$$





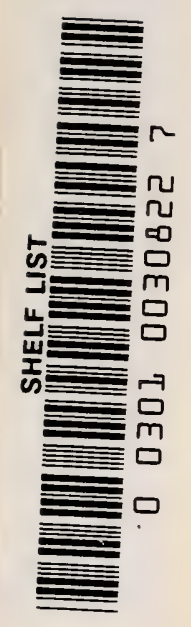




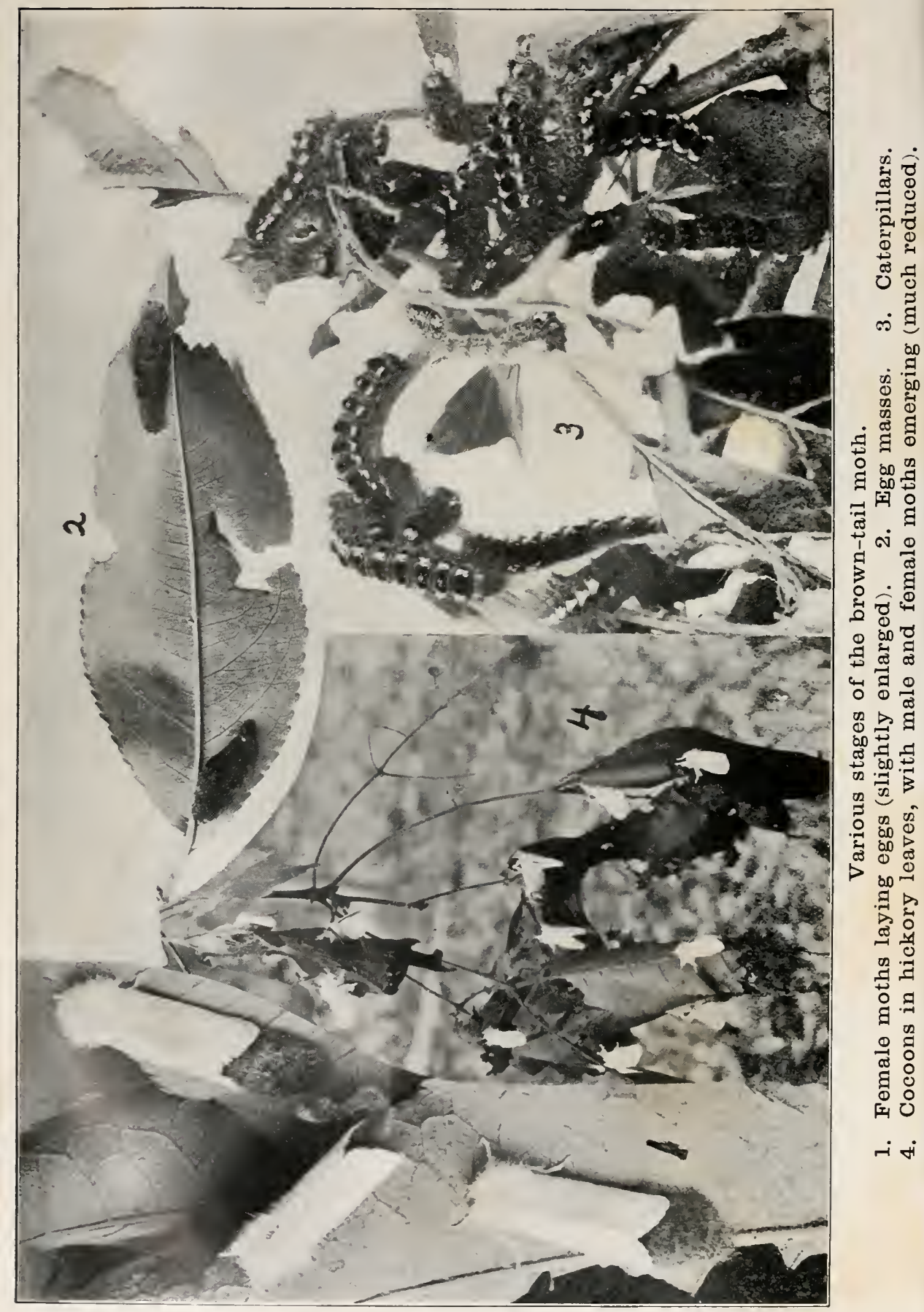


Conmontuealtly of attiassacthusetts.

\section{THE GYPSY AND BROWN-TAIL MOTHS.}

\section{BULLETIN No. 1.}

- Issued from the Office of tile Stperintendent for Suptressingt the Gypsy and Brown-tail Moths.
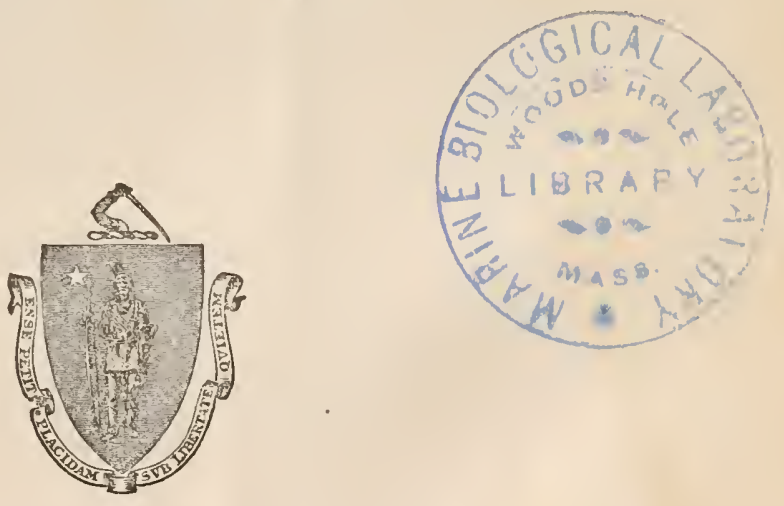

\section{BOSTON :}

WRIGHT \& POTTER PRINTING CO., STATE PRINTERS, 18 Post Office Square. 1905. 



\title{
Commontuealth of attlassathusetts.
}

\author{
OFFICE OF SUPERINTENDENT FOR \\ SUPPRESSING TIL GYPSY AND BRown-TAL MOTHS.
}

The gypsy and brown-tail moths - destructive, introdnced foreign inscets - by act of the Legislature of Massachusetts have bcen declared public nnisances and their suppression authorized and required.

Under chapter 381 of the Acts of 1905 , printed in full at the end of this bulletin, certain duties in the suppression of the gypsy and brown-tail moths devolve upon the Commonwealth of Massachusetts, upon its cities and towns and upon its citizens as individuals.

This bulletin is issued by the State Superintendent for Suppressing the Crypsy and Brown-tail Moths for the guidance of citics and towns and of individual citizens in the work of suppression. To this end, certain essential facts concerning the two insects are herewith prescuted. It is hoped that a pernsal of the bulletin will give city and town officials, and individual property owners as well, a clear idea of their rights and duties under the act. It is incumbent on all citizens to familiarize themsclves with the appearance and habits of the moths and the means best suited for destroying them. Any insects suspected to be either gypsy or brown-tail moths will be gladly identified at this office, and requests for information or advice will receive prompt attention.

A. H. KIRKLAND, Superintendent.

6 Beacon Street, Boston, Mass., Sept. 1, 1905. 




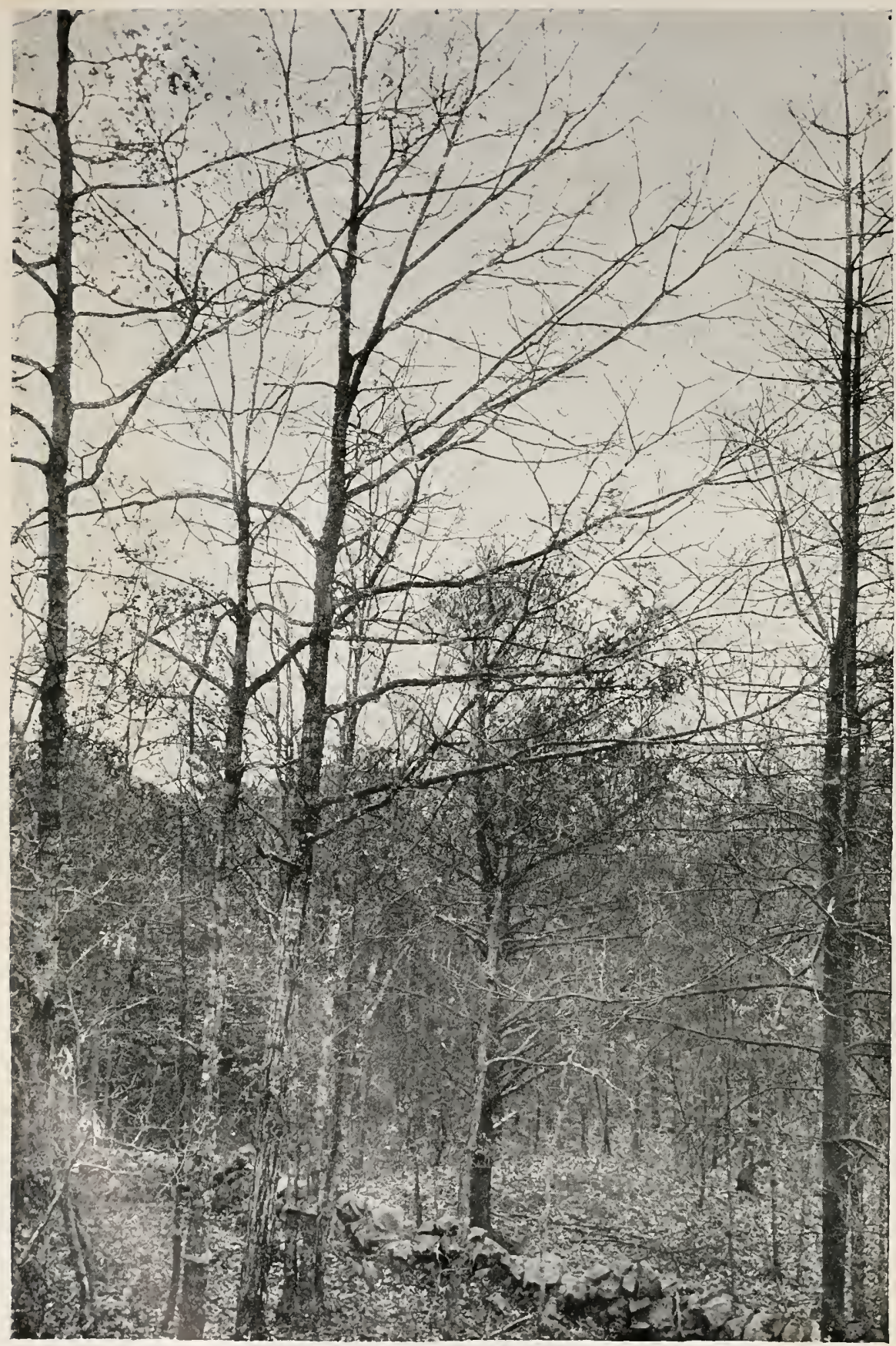

Oak and pine woods attacked by the gypsy moth. Massachusetts Board of Agriculture Report, 1896. 


\section{The Gypsy and Brown-Tail Moths.}

\section{The Gyps Мотн.}

As far back as authentic records exist, the gypsy moth has been a destructive insect pest in Europe; at times increasing enormously and disastrously, then for other periods decreasing, only to increase again and renew its extensive ravages. At the present time it is most numerous and destructive in southern Russia.

Up to the year 1868 the gypsy moth was not known to exist anywhere within the western hemisphere. In that year the insect was brought from Europe by an experimenter to Medford, Mass. Soon escaping, it spread into many cities and towns of eastern Massachusetts, and, increasing enormously, became in 1890 so serious a pest that the Commonwealth began exterminative work against it. This was continued for ten years. By 1900 the State work had so reduced the moth that it was doing little or no serious damage, and had, indeed, ceased to be generally noticed, having been exterminated in many places. The Commonwealth then abandoned its operations against the insect; wherenpon it rapidly gained headway, and soon became again a formidable menace. To-day, in many localities, the gypsy moth occurs in enormous numbers, as it did in 1890 , but it is found over a much larger territory than it occupied at that time.

\section{The Damage cansed by the Gypsy Moth.}

The gypsy moth caterpillar will attack all fruit, shade and woodland trees. It shows a preference for the apple, white oak, red oak, willow and elm. It will devour on occasion nearly every uscful grass, plant, flower, shrub, vine, bush, garden or field crop that grows in Massachusetts.

The caterpillar kills both deciduous and coniferous trees. Woodlands assailed by it in formidable numbers are stripped barc, as in winter, and many trees are killed. Thile several consccutive strippings are usually necessary to cause the death of a healthy decidnous tree, one thorough stripping will kill the white pine and other coniferous trees. Where the gypsy moth abounds in residential districts, it not only eats nearly everything green, but it swarms, in caterpillar form, upon houses, walks and verandas and often enters dwellings. In residential districts most hearily infested by the moth real estate tends to rapid depreciation, so that it sometimes becomes a matter of difficulty to rent or sell property. 


\section{Life History.}

The gypsy moth, like all insects of its class, exists under four different forms during the year.

The Egg. - The eggs of the gypsy moth are laid in July and August in a yellowish, hair-covered mass averaging about one and

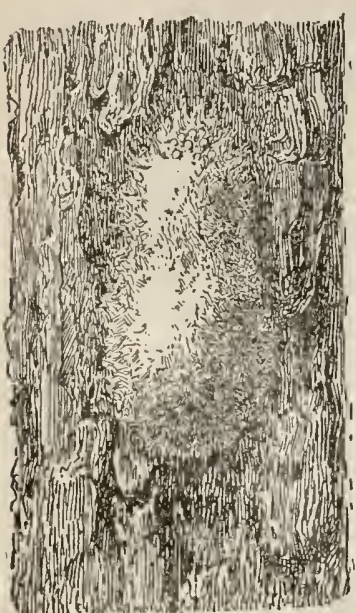

FIG. 1. - Egg cluster of gypsy moth. one-half inches long and about threefourths of an inch wide. To the eye the egg mass resembles a small, tightly stuffed, oval, buff-colored cushion. During winter the color often fades to a dingy white. In this mass, the eggs, to the arerage number of about five hundred, are closely packed with yellowish hair from the body of the female moth. An individual egg is scarcely as large as a pinhead, salmoncolored when first laid, but turning dark in the course of a few weeks.

The Caterpillar or Larva. - The eggs hatch about May 1, and each mass or "cluster" yields a swarm of small caterpillars, the bulk of which become fully grown by midsummer. Gypsy moth caterpillars of any age are decidedly hairy. The head of the caterpillar is large in proportion to its body, this being especially noticeable when it is young.

The mature caterpillar has a dusky or sooty-colored body. Along the back, counting from the head, which is marked with yellow, is a double row of blue spots followed by a double row of red spots. This double row of spots almost invariably may be seen very distinctly on the back of a gypsy moth caterpillar which has attained a length of one inch and a half or more. There are five pairs of blue spots and six pairs of red spots. No other New England larva has this double row of blue and red spots along its back. Until the gypsy moth caterpillar grows to the length of an inch and a half, however, it does not always show very distinctly these pairs of spots. The mature gypsy

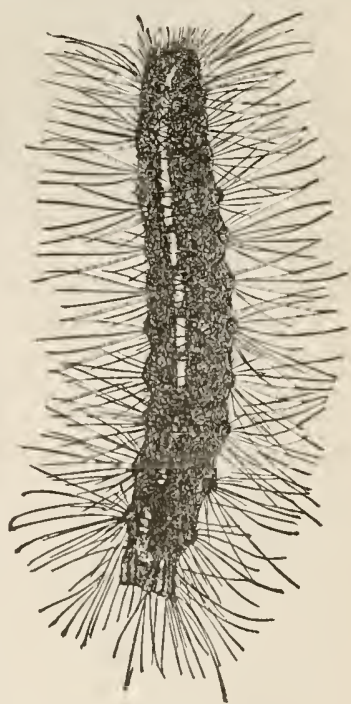

FIG. 2.-Full-grown caterpillar of the gypsy moth. moth caterpillar not infrequently attains a length of three inches. 


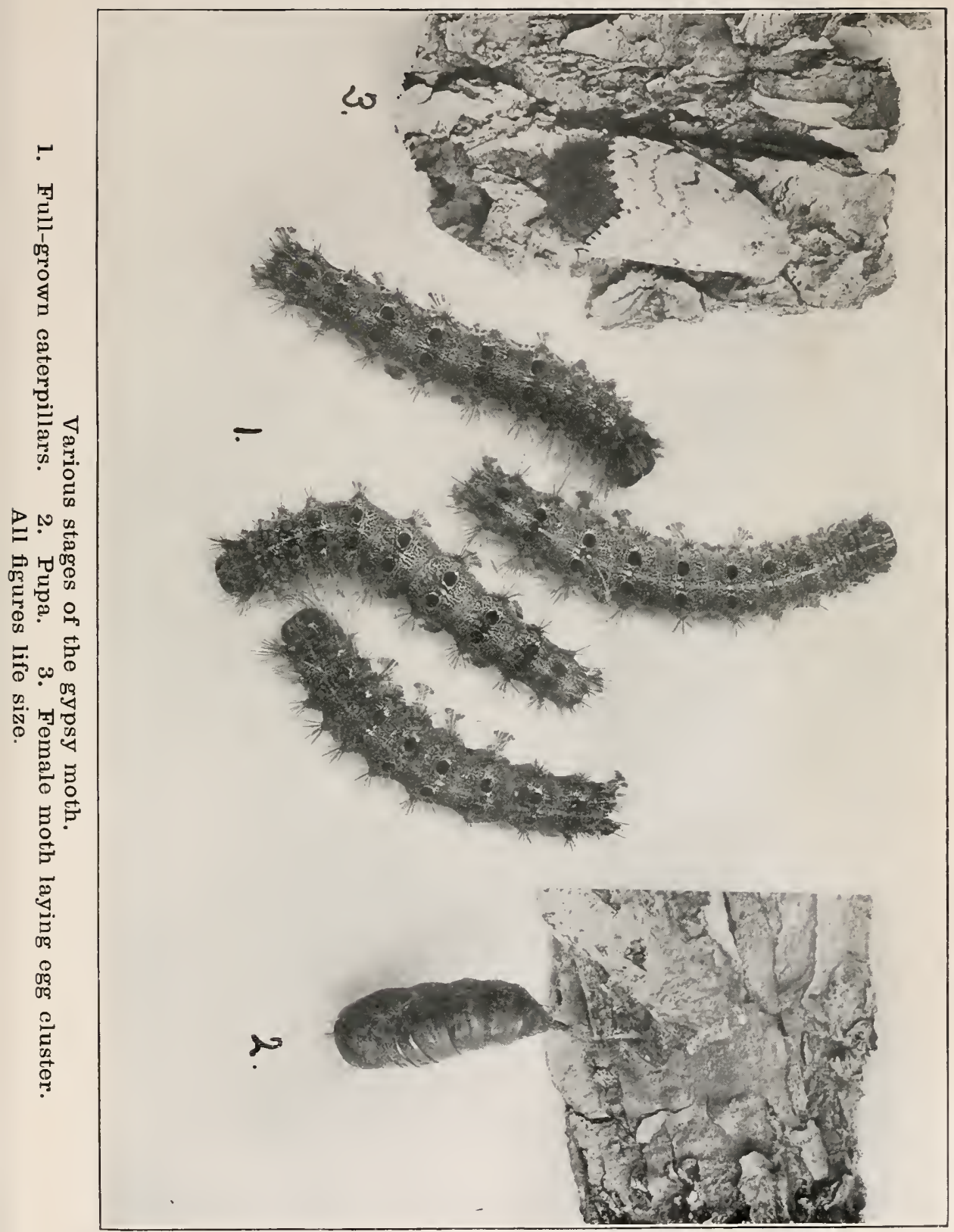



The Pupa. - When fully grown, usually in July, the caterpillar spins a few threads of silk as a supporting framework, casts its skin and changes into a pupa, or, as it is sometimes called, a chrysalis. The pupa is dark reddish or chocolate in color and very thinly sprinkled with light reddish hairs. Unfortunately it resembles the pupæ of certain other moths found in Massachusetts, and cannot, unless by experts, be identified at a glance. The thinly sprinkled, light reddish hairs are, how- ${ }^{\circ}$ ever, characteristic.

The Moth. - From July 15 to August 15 the winged moths emerge from the pupæ, the date varying according to the season and time of pupation. The male moth is brownish-yellow, varying to greenish-brown in color, has a slender body and expands about one and one-half inches. It flies actively by day, with a peculiar zigzag flight.

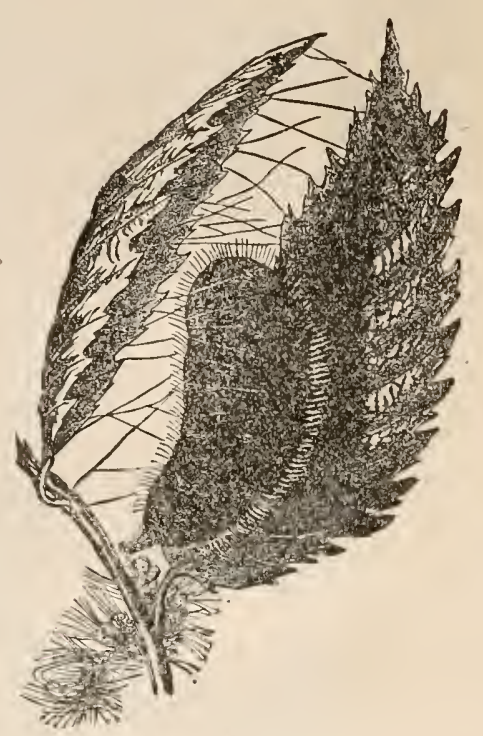

FIG. 3.- Pupa of gypsy moth.

The female moth is nearly white, with numerous small black markings, heavy bodied and sluggish, and expands about two inches. The female does not fly, otherwise the spread of the gypsy moth would be most rapid. After mating, the moths live but a short time. The female dies after depositing her egg mass. The winged moths take no food. All

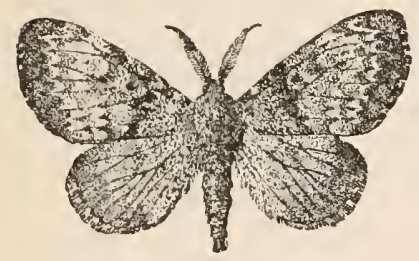

FIG. 4. - Male gypsy moth. damage to foliage is caused by the caterpillars.

\section{Distribution.}

The gypsy moth spreads chiefly during the caterpillar stage. While the caterpillars do not crawl very far from where they hatch, except when there. is a scarcity of food, they have the habit, when small and young, of spinning down on their silken threads from trees, and, falling on vehicles, are then carried from place to place. Electric cars, pleasure and business vehicles, bicycles and automobiles are common means of thus transporting the gypsy moth. The special attention of all those upon whom gypsy moth suppression devolves is therefore directed to the necessity of keeping the neighborhoods of travelled highways free from the insect. The caterpillars often crawl upon 
vehicles standing in an infested spot, and by this means also are carried from one place to another. The egg clusters of the gypsy moth may also be transported upon any of the numerous objects on which they are laid. Freight cars that have stood near infested foliage for a period long enough for the laying of gypsy moth eggs upon them may even thus transport the pest. The gypsy moth is now found in the following cities and towns:-

List of Cities and Towns infested by the Gypsy Moth.

\begin{tabular}{|c|c|c|}
\hline Abington. & IIaverhill. & Plympton. \\
\hline Acton. & Hingham. & Quiney. \\
\hline Amesbury. & Holbrook. & Randolph. \\
\hline Andover. & Hopkinton. & Reading. \\
\hline Arliugton. & Hudson. & Revere. \\
\hline Ashlind. & IHull. & Roekland. \\
\hline Aron. & Hyde Park. & Rockport. \\
\hline Bedford. & Ipswich. & Rowley. \\
\hline Belmont. & Kingston. & Salem. \\
\hline Beverly. & Lawrenee. & Salisbury. \\
\hline Billerica. & Lexington. & Saugus. \\
\hline Boston. & Lincoln. & Scituate. \\
\hline Boxford. & Lymu. & Sherborn. \\
\hline Braintree. & Lynnfield. & Somerville. \\
\hline Brockton. & Malden. & Southborough. \\
\hline Brookline. & Manehester. & Stoneham. \\
\hline Burlington. & Mirblehead. & Stonghton. \\
\hline Cambridge. & Marlborough. & Stow. \\
\hline Canton. & Marshtield. & Sulbury. \\
\hline Carlisle. & Maynard. & Swampreott. \\
\hline Chelsea. & Merlford. & Tewksbury. \\
\hline Cohasset. & Melrose. & Topsfield. \\
\hline Concord. & Merrimac. & Wakefielı. \\
\hline Danvers. & Middleton. & Waltham. \\
\hline Dedhan. & Milton. & Warelian. \\
\hline Dover. & Naliant. & Watertown. \\
\hline Duxbury. & Natick. & Wayland. \\
\hline East liridgewater. & Needlıam. & Wellesley. \\
\hline Essex. & Newbury. & Wenlıam. \\
\hline Everett. & Newburyport. & West Bridgewater. \\
\hline Franingliam. & Newton. & West Newbury. \\
\hline Georgetown. & Nortl Andorer. & Weston. \\
\hline Gloucester. & North lieading. & Weymoutl. \\
\hline Grovelanil. & Norwell. & Whlituman. \\
\hline IIalifax. & Norwoot. & Wilmington. \\
\hline Ilamilton. & Peaborly. & Winchester. \\
\hline Hanover. & Pembroke. & Winthrop. \\
\hline Ilanson. & Plymouth. & Woburn. \\
\hline
\end{tabular}





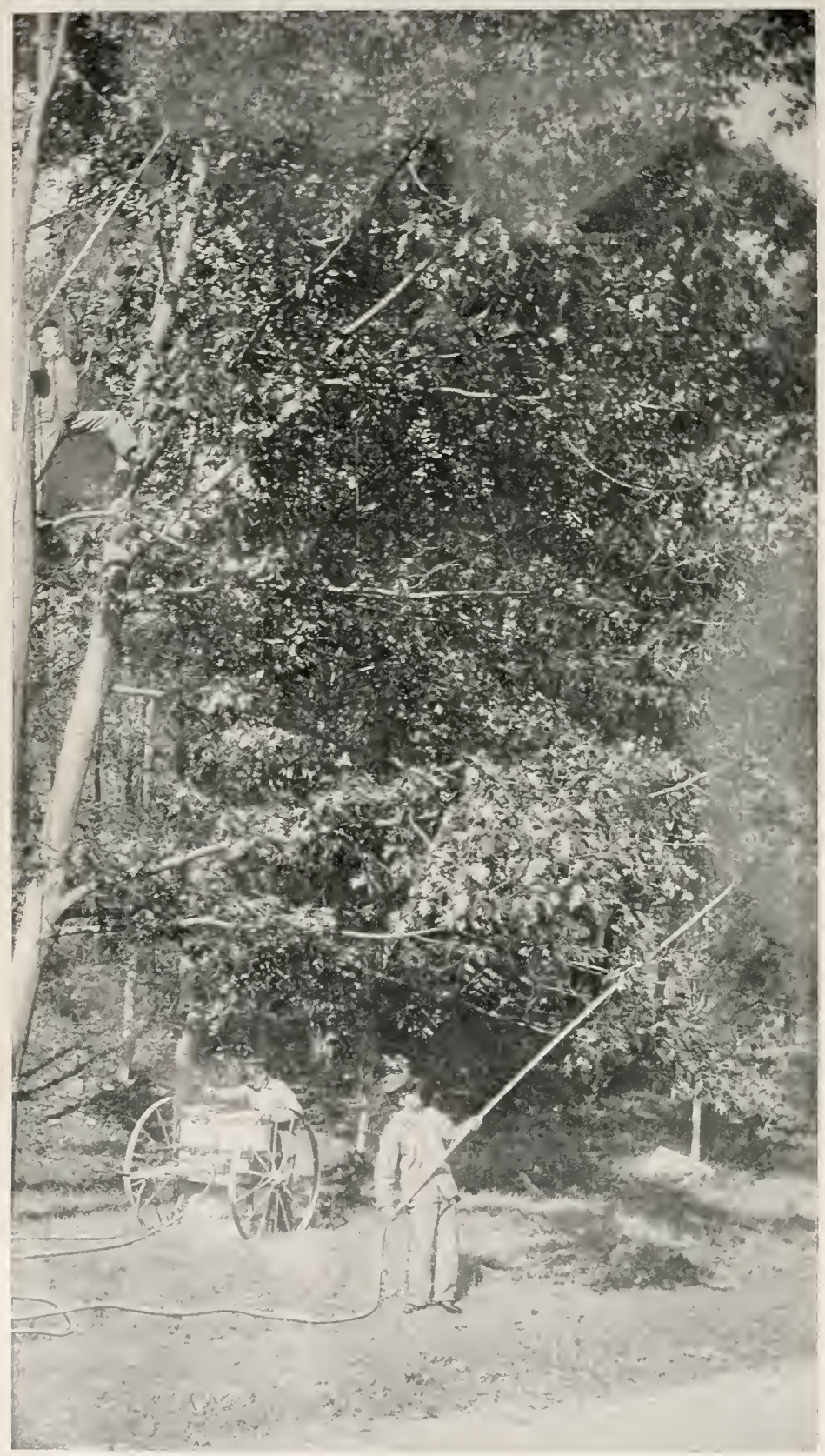

Spraying operations against the gypsy moth. Massachusetts Board of Agriculture Report, 1898. 
While the foregoing list is accurate at this writing (Sept. 1, 1905), there can be but little doubt that the gypsy moth occurs over a considerably larger area. From a knowledge of the existence of large colonies of the moth on main lines of travel in eastern Massachusetts, as well as of the means by which the moth spreads, it seems probable that the insect will ultimately be found at least throughout the eastern part of the State.

\section{Where to look for the Gypsy Moth.}

The Egg. - From August to May the egg masses of the gypsy moth may be found in places near which the moth emerged from the pupa case. In laying, the female moth chooses tree trunks, the under sides of limbs, sheltered crotches and holes in trees, hollow trees, crevices in or under rough bark, etc. The egg clusters are also found on shrubbery, buildings, scattered and heaped rubbish, barrels, boxes and similar objects standing out of doors, wood piles, stone piles, fences, walls, boulders and the like. Gypsy moth egg clusters have been found upon an immense variety of objects, and occasionally may be seen in almost any situation that is not too far from vegetation. The tendency is to deposit the eggs on the lower or inner surface of an object. The moths disregard all rules when they swarm in a place, and their egg clusters may then be found plentifully in sight as well as out, and in all sorts of places, even within buildings.

The Caterpillar. - From May to August the caterpillars may be found in various stages of growth, diminishing in numbers rapidly after July 15 . In the spring the small caterpillars should be looked for on the foliage, feeding principally on the under side of the leaf. As the caterpillars grow, they molt or cast their skin sereral times, and these molted skins are characteristic signs of the presence of the moth. As the caterpillars acquire size, they commence to feed by night, and during the day seek shelter, generally in clusters, on the shady side of tree trunks, beneath large limbs, under rough or loose bark, in holes in trees, under fence rails, in walls, stone heaps, rubbish piles, in short in any accessible place offering shelter from the sun and the birds.

The Pupa. - Gypsy moth pupæ are most abundant during the latter half of July. They are to be found in the same situations as are chosen for depositing the egg clusters, and not infrequently, also, in the foliage of trees and shrubs.

The Moth. - The peculiar zigzag flight of the male moth has already been noted. The large, white, conspicuous female moths sit or crawl on tree trunks, etc., near their pupa cases. In July 
(ehiefly the latter half) and through August these females may be found busily engaged in laying their eggs.

Danger Signs. - The bristly, cast-off molt skins of the gypsy moth eaterpillars, often with the head eases attaehed, may frequently be found in the situations ehosen for the eggs and pupæ. They are often massed in bunehes, and are very eommonly associated with empty gypsy moth pupa cases or hatehed or unhatehed gypsy moth egg elusters.

Gypsy moth molt skins and empty pupa cases are resistant to weather and deeay, and may be found at any season of the year. The presenee in any loeality of sueh molt skin, empty pupa ease or hatehed egg eluster of the gypsy moth indieates the probable presence near by of the living moth in some form, and therefore is a sign of danger not to be disregarded. The hatehed-ont egg masses of a previous year often remain intact in sheltered places, and thus give a clue to the presenee of the inseet.

\section{The Brown-tail Moth.}

This inseet, like the gypsy moth, a eommon European pest of fruit and shade trees, has been an objeet of interest to gardeners from the earliest times. Throughout Europe it is known as the "eommon caterpillar," and aceounts of its habits and periodical ravages are to be found in nearly all European works on entomology and hortieulture. It found its way accidentally to Somerville, Mass., in the early nineties, probably in a shipment of roses from Holland, multiplied, spread, and is now generally disseminated over eastern New England.

\section{Damage by the Brown-tail Moth.}

While at first a pest of the pear and other fruit trees, the browntail moth has now adapted itself to feeding on various speeies of forest trees, wotably the oaks. In the spring, as soon as the buds unfold, the young eaterpillars begin to feed, and where numerous eompletely strip even large trees. When the food supply gives out, they swarm forth along fences, walks, etc., in search of foliage.

The damage by the caterpillars to the fruit trees is only a part of the harm wrought by them. Whenever these insects come in eontaet with human flesh, they produee a most severe and painful nettling. This is due apparently not to any poisonous material in the hairs, but rather to the finely barbed and brittle hairs themselves. So severe is this affection that in many cases people have 


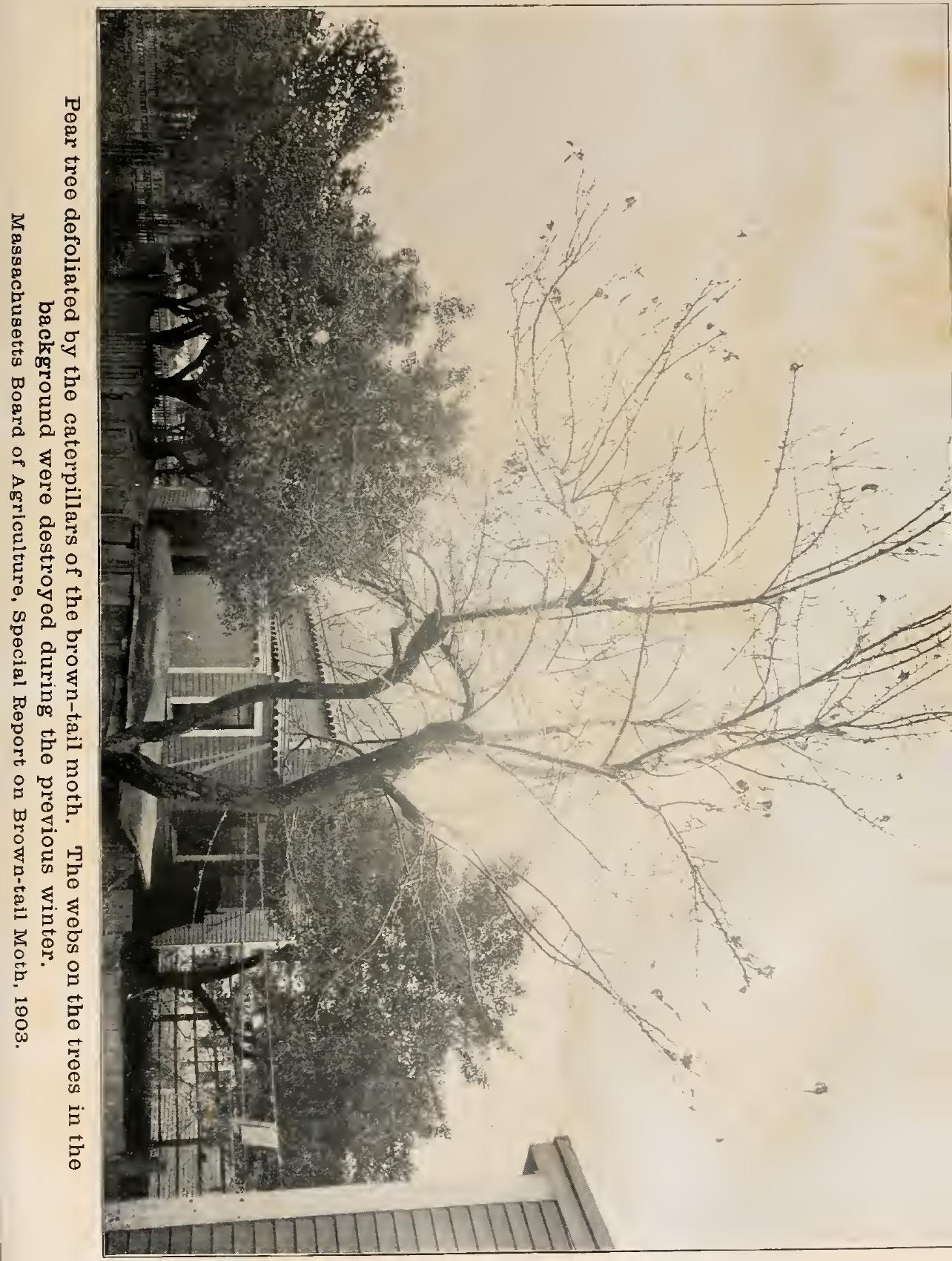




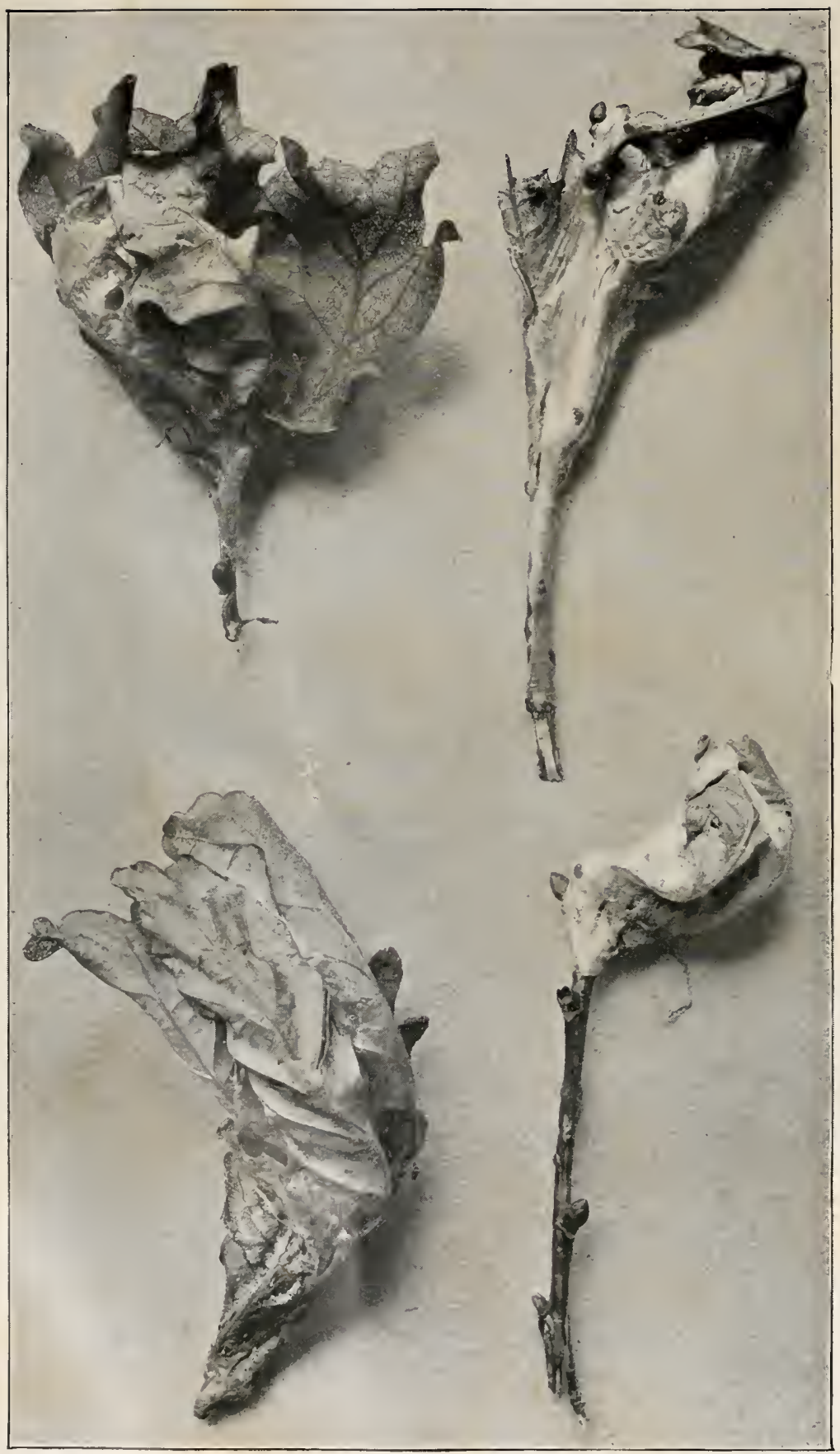

Winter webs of brown-tail moth on English oak.

Photo loaned by Chas. Iradley, Superintendent of Farm School, Thompson's Island. Massachusetts Board of Agriculture, Special Report on Brown-tail Moth, 1903. 
been made serionsly ill by it. The best remedy for it is the liberal use of cooling lotions, or what is more satisfactory, eren if less pleasant, the frec use of common raseline.

Where the brown-tail moth eaterpillar cxists in great numbers, it at times gathers upon houses and even enters them, eausing extreme annoyance. Like the gypsy moth, the brown-tail moth, where it abounds, depreciates the valuc of residential property.

\section{Life History.}

The Egg. - The egg mass of the brown-tail moth somewhat resembles that of the gypsy moth, but it is laid on the under side of a leaf - seldom on a tree trunk - and is smaller and more elongated and of a brighter reddish-brown color. From July 15 to the end of the month, the white moths lay their eggs in brown, hair-eorered masses on the leaves near the top of pear and other trees. Each egg elnster contains about three hundred eggs, elosely paeked in a mass abont two-thirds of an ineh long by one-fourth of an inch wide.

The Caterpillar. - The eggs hateh during Augnst, and the young caterpillars begin to feed in clusters on the upper surface of the leaves. They soon eommenee the work of spinning their winter webs. In making the web a number of leaves in the vicinity of the egg clnsters are drawn together and carefully spun in with a tenacious silken web. The web is grayish in color, eomposed of dead leaves and silk, and is very hard to tear apart. Each web eontains about two hundred and fifty eaterpillars, and raries in length from four to six inehes. With the approaeh of cold weather the eaterpillars enter the web and close the cxit holes. We then have the strange phenomenon of a caterpillar wintering orer when only one-quarter grown, and emerging the following spring

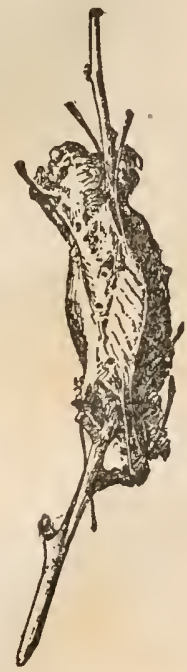

FIG. 5. - Winter web of browntail moth (reduced). to complete its life history. The extremes of cold in Massaehnsetts do not seem to affeet these inseets adversely. They emerge in the spring, usually early in April, eat first the buds and then the blossoms, and attaek the foliage of fruit trees as soon as it derelops. The full-grown caterpillar is about two inehes in length, with a broken white stripe on either side and two conspicnous red dots on the baek near the posterior end.

Stripping the foliage of one tree, they go to others, and continne to cat until full grown, when the cocoons are spun within the leares at the ends of the branehes or sometimes on the tree trunks. 
The Pupu. - The eatcrpillars pupate within their cocoons at the tips of twigs. Usually the mass of cocoons is formed within a spray of leaves, but at times the cocoon is made on a house wall, fence, trce trunk, ete. The pupa is a compact, dark-brown body, about five-eighths of an inch long, with yellowish-brown hairs

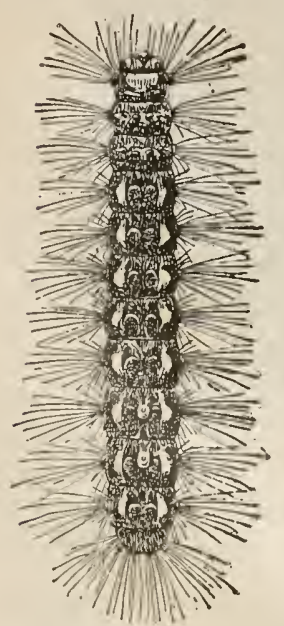

FIG. 6.-Full.g rown caterpillar of the brown-tail moth. scattered over its surface. Pupation takes place the latter part of June, and the moths emerge about the middle of July.

The Moth. - The moths are purc white on the wings. The male is slender bodied, while the female has a conspicuous bunch of brown hair at the tip of the abdomen, hence the name "brown-tail moth." The female has a wing expanse of about one and one-half inches, the male being slightly smaller.

Both the male and female brown-tail moths fly mainly by night, and are greatly attracted to lights. As in the case of the gypsy moth, all the destructive work of the brown-tail moth is done by its eaterpillar, which, unlike the gypsy moth caterpillar, habitually feeds by day. Distribution.

The brown-tail moth is known to have spread at least as far to the northeast as Eastport, Me., and as far south as Cape Cod, Mass. To the west it has been found at Amherst, Mass. The eastern portion of Massachusetts from north to south is now quite solidly infested, though less so south of Boston, and the moth doubtless exists in many communities in and out of Massachusetts from which it has not yet been reported.

The female winged brown-tail moth, like the male, is a strong, swift flyer and ean earry her eggs long distances

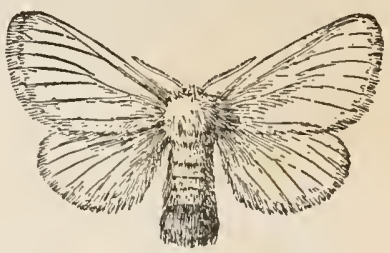

FIG. 7. - Female brown-tail moth. before depositing them. For this reason the brown-tail moth has spread much farther from its point of introduction in Massachnsetts than has the gypsy moth. In its flight the brown-tail moth is often aided by strong winds. It is also transported on steamboats and in eleetrie and steam cars to which it is attracted at night by the lights.

The eaterpillar of the brown-tail moth has, when young, the "spinning down" habit already described in the case of the gypsy 



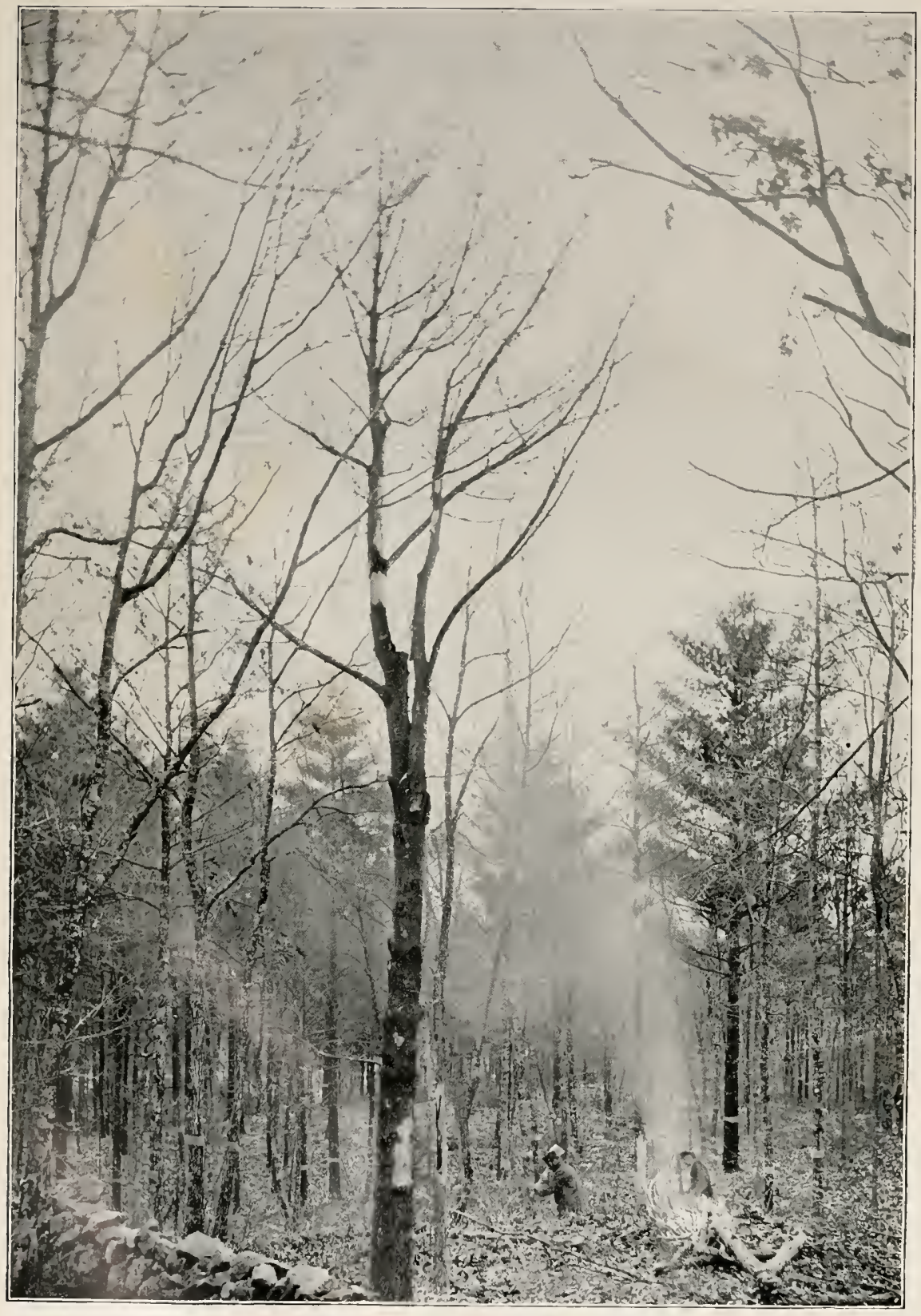

Pine and other trees killed by gypsy moth. Cutting and burning operations in progress.

Massachusetts Board of Agriculture Report, 1899. 
moth caterpillar, and is similarly transported by vehicles and podestrians. The neighborhoods of travelled highways, therefore, should be kept free from the brown-tail as well as from the gypsy moth.

\section{The Species Con'trasted.}

Whe gypsy moth and the brown-tail moth are constantly confused in the minds of many people. The following marked differences between the two should be noted:-

a. The egg cluster of the gypsy moth is rarely found on the under side of a leaf, and is commonly a rather robust-looking object, often two inches long and relatively thick and broad.

The egg cluster of the brown-tail moth is almost always deposited on the mnder side of a leaf, and is smaller and more slender than a typical gypsy moth egg cluster.

b. The gypsy moth caterpillar, when well grown, has a dark grayish or sooty-colored body, marked conspicuously along the back, counting from the head, with a double row of blue spots followed by a double row of red spots.

The brown-tail moth caterpillar, when well grown, is of a bright tawny or orange-brown color, marked along each side of the body by a conspicuous row of pure white spots, and having two bright red spots at the lower end of the back.

$c$. The female gypsy moth has a wing spread of about two and one quarter inches, and her general color is a dingy white lightly streaked and blotched with blackish and faint grayish. Her abdomen has no thick, conspicuous patch of golden or brownish hairs at the tip. Though she has large wings (which she often flutters), she does not fly, but merely crawls short distances.

The female winged brown-tail moth is much smaller than the female gypsy moth, with much less spread of wing. Her color is a remarkably pure, unsullied, snow white. At the tip of her abdomen is a very conspicuous, unmistakable, sharply contrasted, thick, rounded patch of golden or brownish hairs.

The female brown-tail moth is a swift, strong flyer, mainly flying by night, and is greatly attracted to lights.

c. The gypsy moth caterpillar never weaves a nest or wcb in which to hibernate during cold weather. Theogypsy moth winters in the egg form, never as a caterpillar.

The caterpillar of the brown-tail moth always weares a hibernating nest or web in which to rest torpid during the winter. Throughout cold weather the brown-tail moth is in caterpillar form, dormant and snugly ensconced inside its nest, which is placed at or near the tip of a twig. With the warm weather of 
spring the brown-tail moth caterpillar does not " hatch ", but simply awakens to animation, crawls out of the nest and begins to feed.

$e$. The gypsy moth does not, in any of its forms, produce noteworthy irritation of the human skin.

The brown-tail moth caterpillars and cocoons, by reason of their hairs, cause a most annoying and painful irritation. The female brown-tail moths, in their struggles to emerge from the cocoons, often acquire a certain number of caterpillar hairs, and hence are sometimes, though rarely, the cause of the irritation above mentioned.

\section{Remedies against the Moths.}

\section{The Gypsy Moth.}

Egg killing. - No single method of destruction against the gypsy moth is more effective than killing the eggs. The egg masses wherever accessible can be killed from Angust to May by soaking them thoroughly with creosote mixture. The creosote may be applied with a small swab or paint brush. In killing gypsy moth eggs in high trees, it is usually best to work with two men; one man to point out the egg clusters from the ground, another to kill the eggs in the trees. Creosote mixturc may be purchased at agricultural warehouses and seed stores at from fifty cents to one dollar per gallon, depending on quantity.

Where trees and shrubbery (especially low-cost woodland and unimproved tracts of brush) are extensively infested with the eggs of the gypsy moth, the growth should be cut and burned. The eggs are, however, remarkably resistant to firc, and an intense heat applied directly to the clusters is required to kill them all. Where the clusters are very plentiful, burning the ground over with oil to destroy eggs scattered as a result of the cutting of trees and bushes will be required to insure thorough work.

Caterpillar Destruction. - Spraying infested foliage with arsenate of lead at the ratc of ten pounds to one hundred gallons of water is very effective when the caterpillars are small. Any of the common hand outfits will suffice for the spraying of shrubs or flowering plants. For use on trees, a pump mounted on a barrel or hogshead is desirable. The poison should be thoroughly mixed in water, and applied, if possible, on a clear, dry day, in such a manner as to cover the leaves, rather slowly, with a fine mist. The foliage should never be drenched with a stream. When the leaves begin to drip, spraying should at once cease. Spraying should begin at the top of the trees. This work is most effective when done during May and early June. Where tall street trees or trees in 


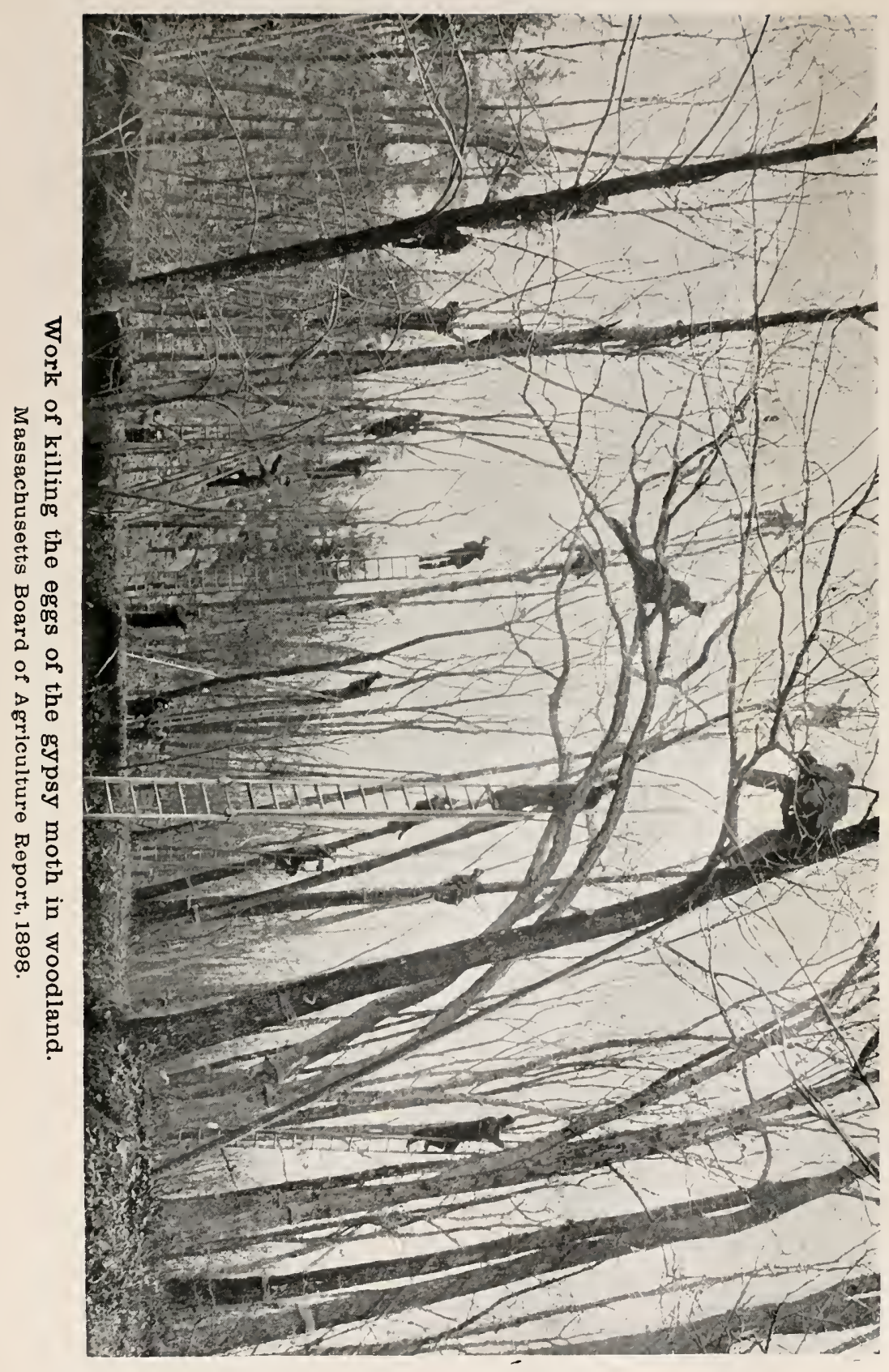




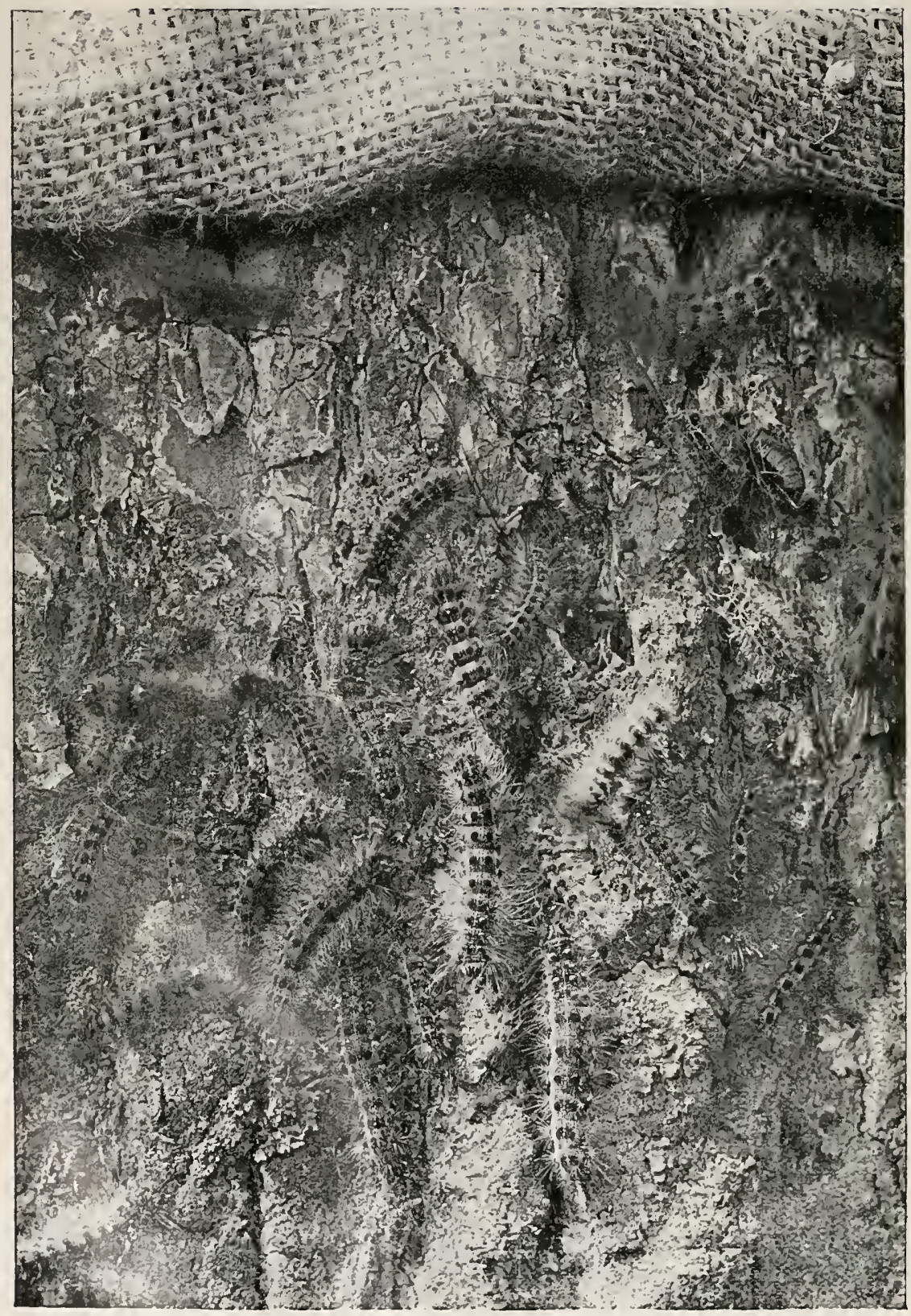

Section of burlap band raised, showing gypsy moth caterpillars that had gathered beneath it on the trunk of an elm tree. Massachusetts Board of Agriculture Report, 1895. 
easily accessible woodland are to be sprayed, the use of a power outfit is to be recommended. Steam or gasoline engine sprayers are not so economieal of the spray as hand pumps, but make a great saving in the cost of labor. Furthermore, with a properly equipped power outfit the work can be done with the greatest possible rapidity. Where arsenate of lead eamnot be obtained, Paris green, one pound to one liundred and fifty gallons of water, may be used, but it should be borne in mind that this insecticide often scorches the foliage, and that it washes off with the first rain. Arsenate of lead is not open to these objeetions.

Burning over infested wood or brush land in May or June is a very effeetive method of destroying gypsy moth caterpillars, and is the logical complement to the method of egg killing by burning previously described. The trees and bushes should be ent before the hatehing time of the eggs, and may be left lying as they fall. A few trees should be left standing, and to these sueh caterpillars as escape the burning will resort for food, and they may then be killed by spraying or by burlapping, as described farther on. The burning of the fallen trees and brush should be done when the caterpillars are very young and small. At this time they quieklysuccumb to flame. When the caterpillars are older, burning is less effective.

If a strip of burlap or other coarse, cheap cloth is tied about an infested

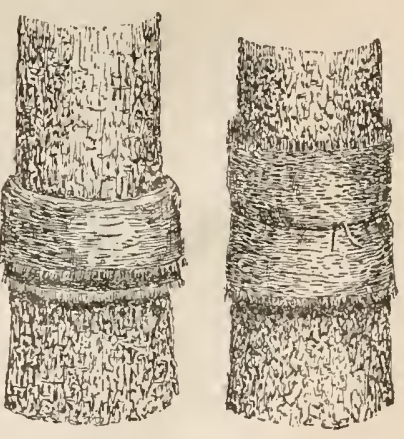

FIG. 8. - Manner of applying the
burlap. tree trunk by the middle, in sueh manner that the flaps hang down, the caterpillars, as soon as they have aequired the nightfeeding habit, will gather under the cloth and can then be destroyed by crushing or by eutting with a sheath knife. The burlaps should be examined daily, or, when the caterpillars are in great numbers in a locality, several times a day. Burlap ean be suecessfully employed from the latter half of May to the first or middle of August, for the caterpillars eommonly pupate under burlap and winged moths lay many eggs under it. It should be borne in mind that the eloth band is in no sense a tree proteetor; nor is it a trap. Its function is simply to give the shelter which the caterpillars seek by day. Serving as it does as a hiding place for various insects, it is better off the tree than on unless it can be attended to and kept clean. At the end of the eaterpillar season, all burlaps should be removed and burned. To insure best results 
on high trees, such as street elms, burlaps should be placed around some of the larger limbs, as well as around the trunk, as many caterpillars will seek shelter up in the trce rather than deseend to the ground. The most effeetive results in using the burlap are obtained where eavities, erevices, ete, in the trees have been first filled with eement or eovered with zine and all loose bark removed. If these hiding plaees are destroyed, nearly all the caterpillars will seek the burlap at some time during the season.

Banding a non-infested tree with inseet lime or other stieky substanee or mixture to keep the eaterpillars out of it is an effeetive means of proteetion, provided the branehes of the tree do not interloek with those of an infested tree, and provided the two do not stand so near that the small caterpillars ean pass from the infested tree to the other by means of their fine threads. A band, of whatever material eomposed, to be effective must remain stieky. When caterpillars are numerous in a plaee, thcy often, in their attempts to eross the band, bridge it over with their threads and dead bodies, with the result that other caterpillars coming later are able to aseend the tree. For this reason and in order that the eaterpillars whieh eolleet beneath may be killed, the stieky band should be frequently inspeeted. If the many caterpillars whieh frequently "herd" below the stieky bands are not killed, they will in time leave the trees for shrubbery, where they are less easily destroyed, there to eomplete their feeding period and transform into moths. Inseet lime, raupenleim, tanglefoot, bodlime, printer's ink or even axle grease are among the materials most used for banding. All may be dangerous to the tree and should be removed after the caterpillar season has passed.

Destroying Pupe and Moths. - Pupæ are eommonly found under the burlap and in other places frequented by the eaterpillars. They are often massed under large branehes or in other sheltered places. In similar loeations the female moths may be found in uumbers. Both forms of the inseet may be erushed by hand to adrantage during July and August.

\section{The Brown-tail Moth.}

The Eggs. - The gathering of leares whieh bear egg masses is only feasible in the ease of shrubs and young trees where the foliage may be reached from the ground. Rose bushes, dwarf fruit trees and ornamental shrubs often may be eleared from the moth in this way.

The Caterpillar. - The winter wobs or nests eontaining the hibernating eaterpillars are conspienous objeets at the tips of twigs from Oetober to $\Lambda$ pril. These webs should be sought out 


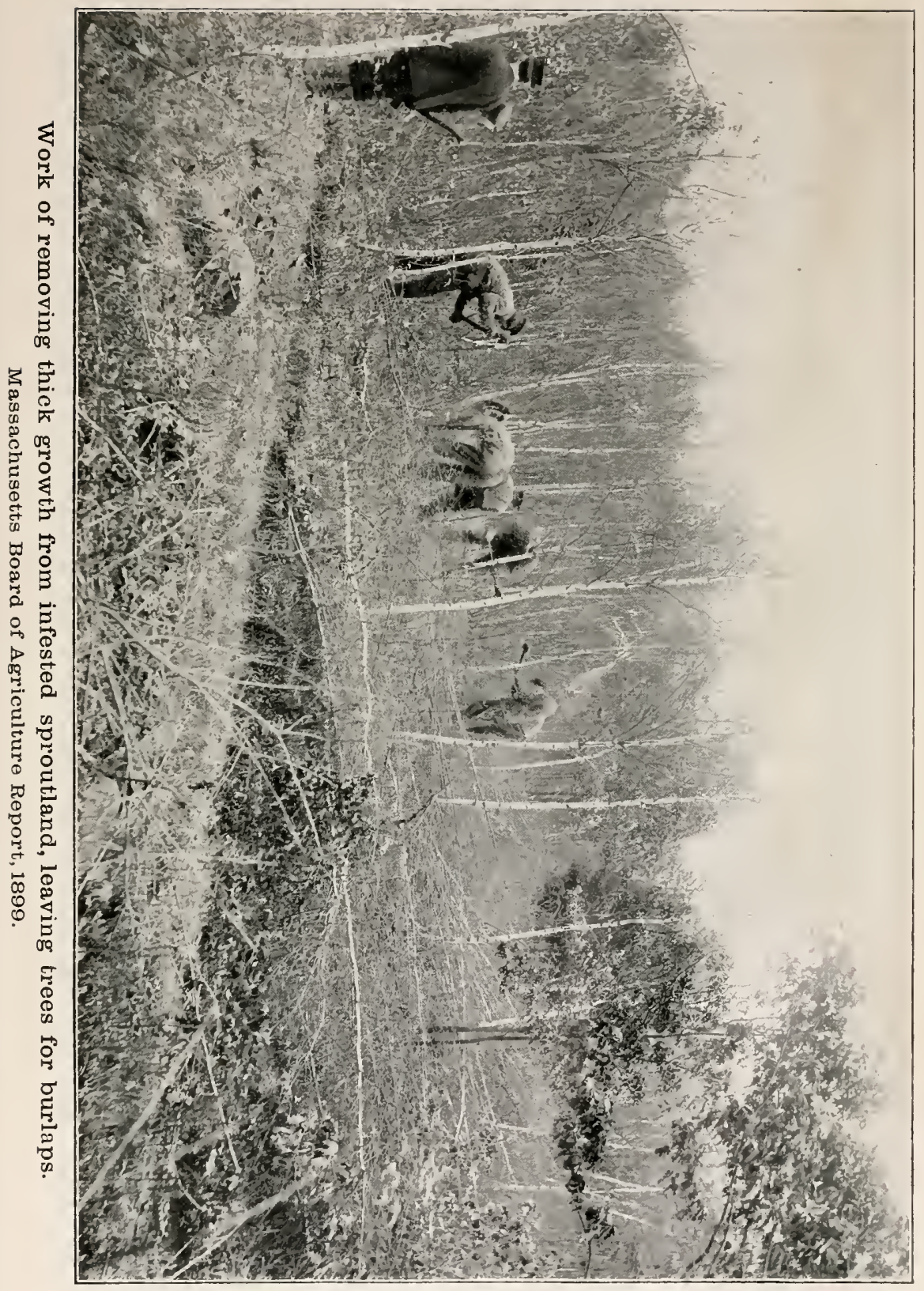




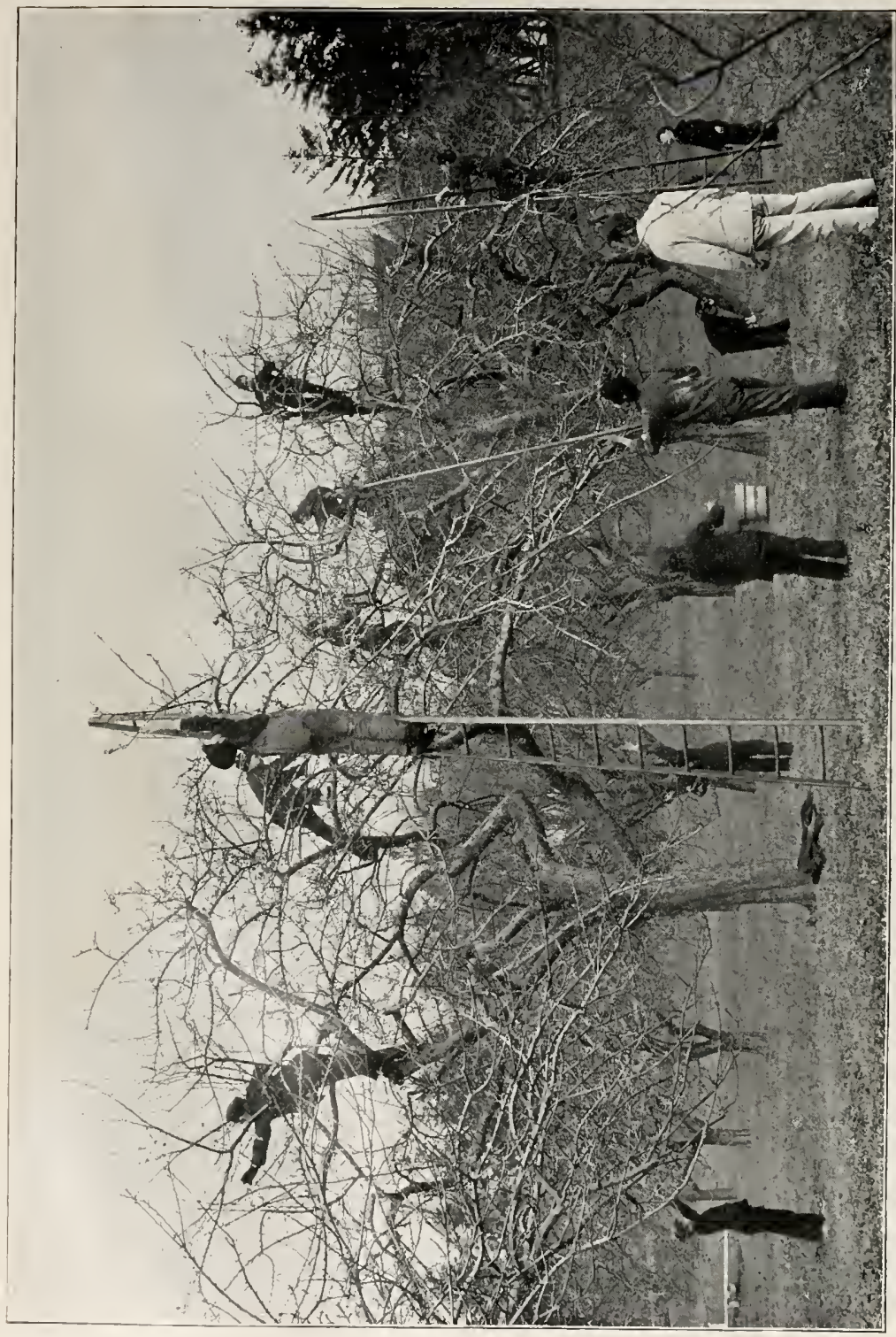

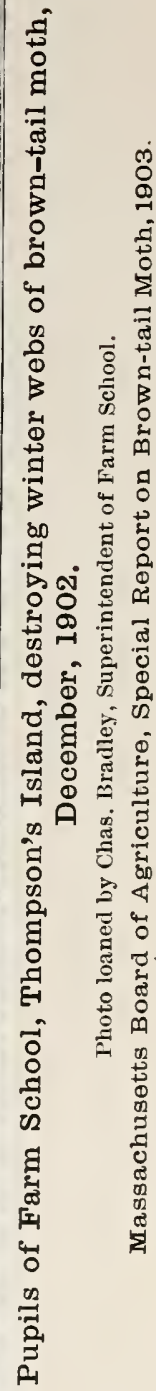


and remored by the use of pole shears or long-handled pruners, and then carefully collected and burned. It is more satisfactory, where possible, to burn the webs in a furnace or store, since, where an open bonfire is used, extra care must be taken to see that none of the webs escape with a mere scorching. When a light snow is on the ground, the work of web destruction and gathering can be carried on to best advantage, although it is desirable that the work should be done as early as possible in the season after the leaves fall. Where tall trees are infested, two men, one to point out the nests from the ground, the other in the tree to cut off the nests, can work more rapidly and economically than one man. It should be borne in mind that webs cut off and thrown on a dump heap as well as those that are beaten off by storms will yield their quota of caterpillars the following spring.

Of all means of combating the brown-tail moth, web destruction as above outlined is the remedy par excellence.

Spraying is very effective against browntail moth caterpillars, since they are much less resistant to the action of poison than are those of the gypsy moth. To secure best results, spraying should be done as soon as the foliage develops in the spring. Five to eight pounds of the arsenate of lead paste to one hundred gallons of water is sufficient for the spray, or, if preferred, one pound of good Paris green kept well stirred in one hundred and fifty gallons of water may be applied. The directions given for spraying gypsy moth caterpillars should be followed in the case of those of the brown-tail moth. Spraying

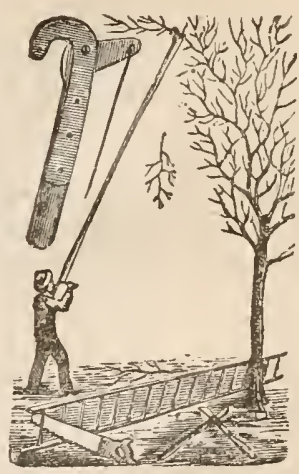

Fig. 9.-Pruning shears suitable for removal ot winter webs: may be done not only in the spring, but also in August when the caterpillars hatch from the egg, except in cases of trees in fruit.

Spraying or sprinkling with kerosene emulsion or strong soal suds is often useful in destroying the swarming caterpillars on fences, walks, etc.

Such trees as are free from brown-tail moths may be protected from the caterpillars which crawl from neighboring estates by applying a sticky band. The banding will not prevent the infestation of the trees by the female winged moths, which, flying in July, will alight on the foliage of such trees and deposit their egg clusters thereon. It is therefore clear that sticky banding, when used against brown-tail caterpillars, has a more strictly limited usefulness than in the case of the gypsy moth. 
The Pupe. - When the caterpillars have changed to pupæ enclosed by their cocoons, these may be gathered, although the work is likely to be attended by severe inflammation of the skin from contact with the nettling hairs. Cocoons thus gathered should be placed in a barrel covered with mosquito netting, so that any parasites may escape while the moths are confined. Brown-tail moth pupæ are most numerous during the latter half of June.

The Moths. - As has already been mentioned, the moths assemble in great numbers around electric and other lights. It often occurs that a lamp pole on a morning during the flying season is covered by hundreds if not thousands of the winged moths. In such cases the free use of the hose will wash down and kill the insects. No effective form of lamp trap has yet been devised, and, in fact, it is not at all clear that the brown-tail moth can be combated economically in the winged stage.

\section{A Summary of the Law.}

In the suppression of the gypsy and brown-tail moths, certain duties under the law devolve not only upon the Commonwealth but also upon cities and towns and upon citizens as individuals. Attention is hereby called to chapter 381 of the Acts of 1905 , which defines these duties at length and which is printed in full at the end of this bulletin.

The following summary of the law is designed to give its salient points:-

\section{The Moths are Public Tuisances.}

The gypsy and brown-tail moths are declared public nuisances and their suppression is required.

\section{The Superintendent of Suppression.}

A superintendent, appointed by the Governor, with power, subject to the Governor's approval, of appointing agents and assistants, has entire general charge of the work of suppressing the moths.

\section{Duties of Cities, Towns and Individuals.}

('ities and towns (under the advice and general direction of the superintendent, and by such agent as they may designate or appoint) are required, under penalty for neglect, to destroy the eggs, pupæ and nests of the gypsy and the brown-tail moths within their limits :

Excepting that such work is not to be done by cities and towns on property controlled by the Commonwealth; nor is it to be done upon private property, excepting where the owners of the same 
fail to destroy the eggs, pupæ and nests of the moths, in aeeordance with the terms of the official notice to private owners, noted in the section here following:-

\section{Sotice to Privute Owners.}

The mayor of evcry eity and the selectmen of every town shall, at suitable times, notify every owncr of land located therein whieh is infested with the moths, requiring him to destroy the eggs, pupa and nests of the moths within a specified timc.

When the mayor or seleetmen decide that the cost of suel destruction (on lands eontiguous and under one ownership) will excecd one-half of one per cent. of the assessed valuation of the lands, then they may designate in the notiee a part only of sueh lands on whieh the destruetion shall take plaee.

\section{Failure of Pricate Owners to destroy Woths.}

If the owner does not, as required by the terms of the aforesaid notiee, destroy the eggs, pupe and nests of the moths, then the eity or town, subject to the approval of the state superintendent, shall destroy them, and shall assess upon sueh aforesaid lands the actual cost of so doing, to an amount, howerer, not exeeeding one-half of one per cent. of the assessed valuation of the land.

This amount, so assessed, shall be colleeted in the form of taxes, and eonstitutes a lien upon sneh lands.

\section{Redress by Abatement and Appeal.}

The assessor's may abate the moth assessment in the case of any private land owner deeided by them to be unable to pay it because of age, infirmity or poverty.

Appeal to the county superior court, with speeial provision for prompt hearing, is provided by the statute for any person aggriered by assessment on aceount of this work; provided a complaint is entered within thirty days of notiee of sueh assessment.

\section{Appropriation by the Commonwealth.}

T'o meet the expenses ineurred under its moth-suppression law, the Commonwealth has appropriated $\$ 300,000$. Of this sum, $\$ 75,000$ may be expended during $1905, \$ 150,000$ (and any unexpended balance) during 1906, and $\$ 75,000$ (and any unexpended balanee) during 190\%, up to May 1, 190\%, inelusive.

For the purpose of experimenting with natural enemies for destroying the moths, $\$ 10,000$ is additionally appropriated for eaeh of the years 1905, 1906 and $190 \%$. 


\section{Reimbursements to Cities and Towns.}

1. Cities and towns with valuation of real and personal estate of $\$ 12,500,000$ or more, having spent $\$ 5,000$ in any one calendar year, shall be reimbursed ammually 50 per eent (one-half) of all further expenditure.

2. Cities and towns, with valuation less than $\$ 12,500,000$ and more than $\$ 6,000,000$, having spent an amount equal to onetwenty-fifth of one per eent of sueh valuation in one year, shall be reimbursed amnually 80 per cent (four-fifths) of all further expenditure.

3. Towns with valuation less than $\$ 6,000,000$, having spent an amount equal to one-twenty-fifth of one per eent of such valuation in one year, shall be reimbursed once in sixty days for all further expenditure.

\section{Suppression by the Commonwealth.}

After any town of less than $\$ 6,000,000$ valnation has expended in suppressing the gypsy and brown-tail moths an amount equal to one-twenty-fifth of one per eent of its real and personal valuation, then the Commonwealth shall expend within such town sueh auditional sum for suppression as the superintendent, with the adviee and eonsent of the Govcrnor, in such ease shall reeommend.

\section{Limits to required Expenditure by Cities and Towns.}

No city or town with an assessed real and personal valuation of more than $\$ 6,000,000$ shall be requircd to expend in the suppression of the moths, during any one full year, more than one-fifteenth of one per eent of sueh valuation. No town with an assessed real and personal valuation of less than $\$ 6,000,000$ shall be required to thus expend during any one full year more than one-twenty-fifth of one per eent of sueh valuation.

\section{Vuluations of $190+$ taken as Basis.}

Wherever valuations of real and personal property are referred to in the gypsy and brown-tail moth suppression law, the valuations of $190 t$ are meant.

\section{Iilful Resistunce or Obstruction.}

Wilful resistance to or obstruetion of any agent of the Commonwealth or of any city or town, while lawfully engaged in the execution of the purposes of the moth-suppression law, is forbidden under penalty. 
The Woth-suppression Law should be Studied.

The law concerning the suppression of the gypsy and brown-till moths is set forth in full in chapter 381 of the Aets of 1901.5 , printed at the end of this bulletin. The close attention of all persons concerned is again liereby direeted to this law.

\section{WARNING.}

Many property owners prefer to hire experts to destroy the moth pests on their estates, and this is often the most economical and effeetive plan, partienlarly in the case of the gypsy moth. This offiec has prepared a list of reliable persons who are engaged in the work of moth suppression as a business, and the same may be liad on request. It should be understood, however, that the superintendent assumes no responsibility for the snccess or the cost of sueh work.

It is to be regretted that several unscrupulous persons have made a practice of applying worthless treatments to trees, at large cost to the owner, and even, in some cases, have claimed that they were offieial representatives of this office. It should be elearly understood that no employee of this office is anthorized to do such work, to be paid for direetly by property owners. Any case of a person making representations to the contrary should be bronght to the attention of the police and this office notified.

The superintendent has organized a small corps of trained agents and inspectors who are engaged in examining the infested territory and in directing the work of the varions cities and towns. The central office is prepared to advise officials in charge of local work, as well as private citizeus, eoneerning the best methods of combating the moths, and to render any assistance in its power.

If our trees are to be saved from these insects, the hearty co-operation of all eitizens will be neeessary. Without such cooperation little can be accomplished; with it, the posts can be brought under control.

\section{A. H. KIRKLAND,}

Superintendent.

OFfice, 6 Beacoy Street, Bostos, Mass.

Connected by telephone. 



\title{
LAW RELating TO GYPSY AND BROWN-TAIL MOTHS.
}

\author{
[CinAP. 381.] \\ AY ACt to PRovide FOR SUPPIESSLA THE GYPSY AND BROWN TAIL \\ MOTHS.
}

Be it enacted, etc., as follows:

Section 1. For the purposes of this act the pupre, nests, eggs and caterpillars of the gypsy and brown tail moths and said moths are hereby declared public nuisances, and their suppression is authorized and required; but no owner or occupant of an estate infested by such nuisance shall by reason thereof be liable to an action, civil or criminal, except to the extent and in the manner and form herein set forth.

SEction 2. The governor, by and with the consent of the council, shall appoint a superintendent for suppressing the gypsy and brown tail moths and shall determine his salary. The governor may, with the consent of the council, remove said superintendent at any time for such cause as he shall deem suflicient. In case of the death, removal or resignation of the superintendent the gorernor shall forthwith appoint a successor. On or before the third Welnesday in January in ench year the superintendent shall make a report of his proceedings to the general court, which shall be a public document and shall be printed. Said report shall separate so far as is practicable the expenditures on work arrainst the gypsy moth from those on work against the brown tail moth in each city and town.

Sectior 3. The said superintendent shall act for the Commonwealth in suppressing said moths as public nuisances, in accordance with the provisions of this act. For this purpose he shall establish an oftice and keep a record of his doings and of his receipts and expenditures, and may make rules and regulations. He may employ such clerks, assistants and agents, including expert advisers and inspectors, as he nay deem necessary and as shall be approved by the governor. IIe may make contracts on behalf of the Commonwealth; may act in co-operation with any person, persons, corporation or corporations, including other states, the United States or foreign governments; may conduct investigations and accumulate and distribute information concerning said moths; may devise, use and require all other lawful means of suppressing or preventing said moths; may lease real estate when he deems it necessary, and, with the approval of the board in charge, may use any real or personal property of 
the Commonwealth; may at all times enter upon the land of the Commonwealth or of a municipality, corporation, or other owner or owners, and may use all reasonable means in carrying out the purposes of this act; and, in the undertakings aforesaid, may, in accordance with the provisions of this act, expend the funds appropriated or donated therefor; but no expenditure shall be made or liability incurred in excess of such appropriations and donations.

SECrIox 4. Cities and towns by such public ofheer or board as they shall designate or appoint, shall, under the advice and general direction of said superintendent, destroy the eggs, pupe and nests of the gypsy and brown tail moths within their limits, except in parks and other property umler the control of the Commonwealth, and except in private property, save as otherwise provided herein. When any eity or town shall have expended within its limits city or town funds to an amount in excess of five thousand dollars in any one calendar year, in suppressing gypsy or brown tail moths, the Commonwealth shall reimburse such eity or town to the extent of fifty per cent of such excess above said five thousand dollars.

Cities or towns, where one twenty-fifth of one per cent of the assessed valuation of real and personal property is less than five thousand dollars, and where the assessed valuation of real and personal property is greater than six million dollars, shall be reimbursed by the Commonwealth to the extent of eighty per cent of the amount expended by such cities or towns of city or town funds in suppressing the gypsy and brown tail moths in any one calendar year, in excess of said one twenty-fifth of one per cent.

In the case of towns where the assessed valuation of real and personal property is less than six million dollars, after they have expended in any one calendar year town funds to an amount equal to one twenty-fifth of one per cent of their assessed valuation of real and personal property, the Commonwealth shall expend within the limits of such towns, for the purpose of suppressing the gJpsy and brown tail moths, such an amount in addition as the superintendent with the advice and consent of the governor shall recommend. Disbursements male by said last named towns in excess of said one twenty-fifth of one per cent shall be reimbursed by the Commonwealth every sixty days; but in the case of all others the Commonwealth shall reimburse cities and towns annually according to the provisions of this act.

No city or town shall be entitled to any reimbursement from the Commonwealth until it has submitted to the auditor of the Commonwealth itemized accounts and vouchers showing the definite amount expended by it for the purpose of this act; nor shall any money be paid out of the trcasury of the Commonwealth to eities or towns, pursuant to the provisions of this act, until said vouchers and aecounts have been approved by the anditor of the Commonwealth.

For the purposes of this section the years nineteen hundred and five and ninetcen hundred and seven shall be considercd half ycars, and the valuation for the year nineteen lundred and four shall be taken as a basis. 
Sectrox 5. When, in the opinion of the superintendent, any eity or town is not expending a sufficient amount for the abatement of said nuisance, then the superintendent shall, with the advice and consent of the governor, order such city or town to expend such an amount as the superintendent shall deem necessary : provided, that no eity or town where the assessed valuation of real and personal property exceeds six million dollans shall be required to expend during any one full year more than one fifteenth of one per cent of such valuation, and that no town where the assessed raluation of real and personal property is less than six million dollars shall be required to cxpend during any one full ycar more than one twenty-fifth of one per cent of such valuation. For the purposes of this section the valuation of the year nineteen hundred and four shall bc used.

Any city or town failing to comply with the directions of the said superintendent in the performance of said work within the date specified by lim shall pay a fine of one hundred dollars a day for failure so to do; said finc to be collected by information brought by the attorney-general in the supreme judicial court for Suffolk county.

SECTION 6. The mayor of every city and the selectmen of every town shall, on or before the first day of November in each year, and at such other times as he or they shall see fit, or as the state superintendent may order, cause a notice to be sent to the owner or owners, so far as can be ascertained, of every parcel of land therein which is infested with said moths; or, if such notification appears to be impracticable, then by posting such notice on said parcels of land, requiring that the eggs, pupe and nests of said moths shall be destroyed within a time specified in the notice.

When, in the opinion of the mayor or selectmen, the cost of destroying such eggs, pupx and nests on lands contiguous and hcld under one ownership in a city or town shall exceed one half of one per cent of the assessed value of said lands, then a part of said premises on which said eggs, pupe or nests shall be destroyed may be designated in such notice, and such requirement shall not apply to the remainder of said premises. The mayor or selectmen may designate the manner in which such work shall be done, but all work done under this section shall be subject to the approval of the state superintendent.

If the owner or owners shall fail to destroy such eggs, pupæ or nests in accordance with the requirements of the said notice, then the city or town, acting by the public officer or board of such city or town designated or appointed as aforesaid, shall, subject to the approval of the said superintendent, destroy the same, and the amount actually expended thereon, not exceeding one half of one per cent of the assessed raluation of said lands, as heretofore specified in this section, shall be assessed upon the said lands; and such an amount in addition as shall be required shall be apportioned between the city or town and the Commonwealth in accordance with the provisions of section four of this act. The amounts to be assessed upon private estates as herein provided shall be assessed and collccted, and shall be a lien on said estates, in the same manner and with the same effect as is provided in the case of assessments for street watering. 
SeCrion 7. If, in the opinion of the assessors of a city or town, any land therein has received, by reason of the abatement of said nuisanees thereon by said superintendent or by said city or town, a speeial benefit beyond the general advantage to all land in the city or town, then the said assessors shall determine the value of sueh speeial bencfit and shall assess the amount thereof upon said land: provided, that no sueh assessment on lands eontiguous and held under one ownership shall exeeed one half of one per cent of the assessed valuation of said lands; and provided, that the owner or owners shall have deducted from such assessment the amount paid and expended by them during the twelve months last preceding the date of such assessment toward abating the said nuisances on said lands, if, in the opinion of the assessors, such amount has been expended in good faith. Sueh assessment shall be a lien upon the land for three years from the first day of January next after the assessment has been made, and shall be eollected under a warrant of the assessors to the eollector of taxes of such city or town, in the manner and upon the terms and conditions and in the exercise of the powers and duties, so far as they may be applicable, prescribed by chapter thirteen of the Revised Laws relative to the colleetion of taxes.

Real estate sold hereunder may be redeemed within the time, in the manner, and under the provisions of law, so far as they may be applieable, set forth in chapter thirteen of the Revised Laws for the redemption of land sold for taxes.

A person aggrieved by such assessment may appeal to the superior court for the county in whieh the land lies, by entering a complaint in said eourt within thirty days after he has had aetual notiee of the assessment, which complaint shall be determined as other causes by the court without a jury. The eomplaint shall be heard at the first sitting of said court for trials without a jury after its entry; but the court may allow further time, or may advance the case for speedy trial, or may appoint an auditor as in other eases. The eourt may revise the assessment, may allow the reeovery baek of an amount wrongfully assessed which has been paid, may set aside, in a suit begun within three years from the date thereof, a collector's sale made under an erroneous assessment, may award costs to either party and may render sueh judgment as justice and equity require.

If, in the opinion of the assessors, the owner of an estate npon whieh an assessment, as aforesaid has been made is, by reason of age, infirmity or poverty unable to pay the assessment, they may upon application abate the same. Every city or town in rendering an aceount to the state auditor as provided for in section four of this aet shall deduet from such amount as it has expended in excess of one twenty-fifth of one per cent or of five thousand dollars as provided in said seetion, the total amount it has reeeived for work performed under section six of this act during the term covered by the account: provided, sueh work was performed under such conditions as require reimbursement in whole or in part by the State.

SECTION 8. To meet the expenses incurred under authority of this aet, there shall be allowed and paid out of the treasury of the Commonwealth, 
during the period up to and including May first, nineteen lundred and seven, the sum of three hundred thousand dollars. Of this amount seventy-five thousand dollars may be expended during the ealendar year nineteen lundred and five; one hundred and fifty thousand dollars, and any unexpended balance of the previous year, may be expended during the calendar year nineteen hundred and six; and seventy-five thousand dollars, and any unexpended balance of the previous years, may be expender during the calendar year nimeteen hundred and seven, up to and including May first.

Section 9. An additional sum of ten thousand dollars in each of the years nineteen hundred and five, nineteen hundred and six and nineteen hundred and seven may, in the discretion of the state superintendent, be expended by him for experimenting with parasites or natural enemies for destroying said moths, and any unexpended balance of any ycar may be expended in the subsequent years.

Section 10. Chapter two hundred and ten of the acts of the year eighteen hundred and ninety-one and sections one and two of chapter five hundred and forty-four of the acts of the year eighteen hundred and ninety-cight and section two of chapter fifty-seven of the acts of the year nineteen hundred and two, are hereby repealed.

Section 11. A person who wilfully resists or obstruets the superintendent or an official of a eity or town, or a servant or agent duly employed, while lawfully engaged in the execution of the purposes of this aet, shall forfeit a sum not exceeding twenty-five dollars for each offence.

SECTION 12. Valuations of real and personal property of the year nineteen hundred and four shall govern the provisions of this aet.

SECTION 13. This act shall take effect upon its passage. [Approved May 8,1905 . 

